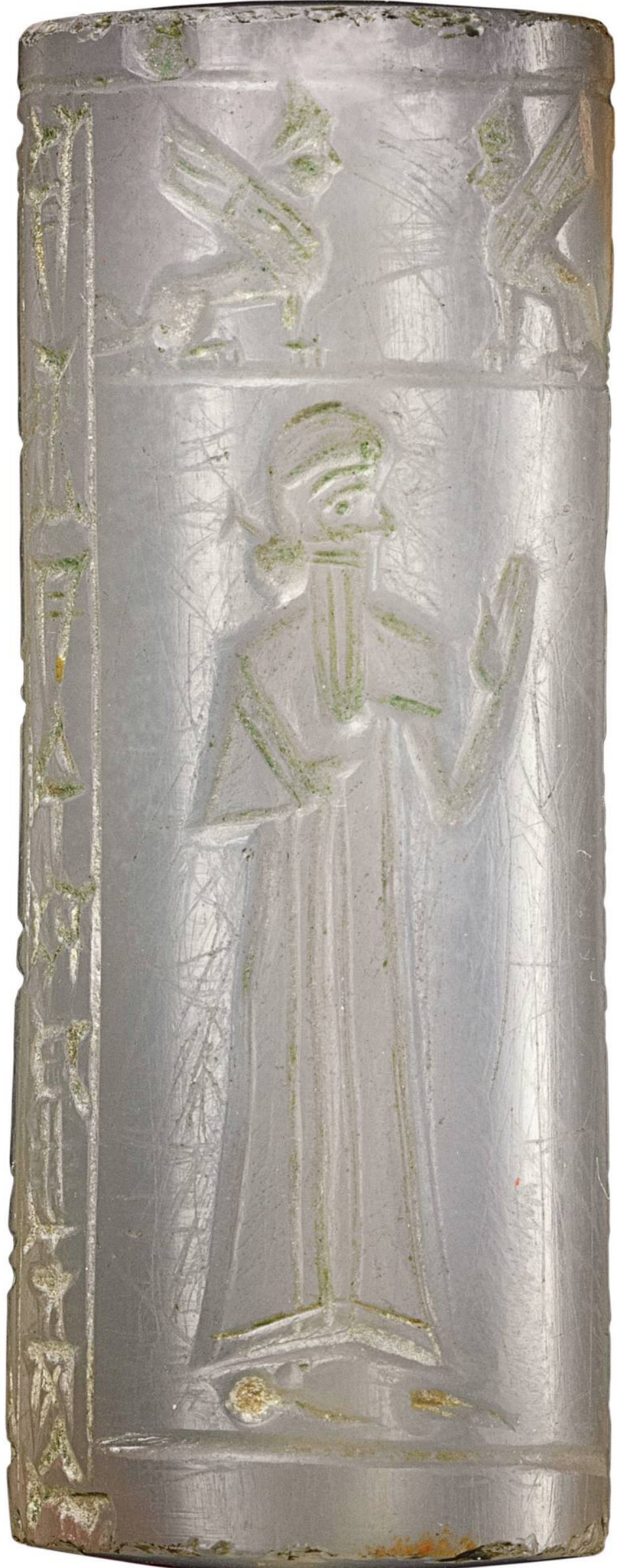

This content downloaded from 128.122.149.092 on December 15, 2018 05:37:02 AM All use subject to University of Chicago Press Terms and Conditions (http://www.journals.uchicago.edu/t-and-c). 


\section{GINA KONSTANTOPOULOS}

\section{Inscribed Kassite Cylinder Seals in the Metropolitan Museum}

The Kassite dynasty ruled Babylonia, in the south of Mesopotamia, or modern-day Iraq, for nearly four centuries, beginning after 1595 B.c. and collapsing finally in 1155 B.c. The Kassites were not themselves native to the region but may have come from the east, near the region of the Zagros Mountains.' They quickly adopted the native Mesopotamian culture of their new home, which qualities are reflected in their art, including cylinder seals. This article is concerned with the sixteen Kassite-period cylinder seals in the collection of The Metropolitan Museum of Art. These seals, cylindrical beads that were carved in intaglio with images and text, were rolled across damp clay to create a raised impression. They served as administrative tools in the ancient Near East, used to mark clay cuneiform tablets to provide verification of the content of the text or to invoke the seal owner's presence. They were also personal 
fig. 1 Cylinder seal of Lamassani, with modern impression and line drawing. Carnelian, H. $7 / 8$ in. $(2.2 \mathrm{~cm})$ The Metropolitan Museum of Art, Gift of Georg Hahn, $1947(47.115 .3)$

fig. 2 Cylinder seal of Kunnaiatum with modern impression and line drawing. Jasper, H. $1 \frac{1}{2}$ in. $(3.9 \mathrm{~cm})$ The Metropolitan Museum of Art, Gift of The Right Reverend Paul Moore Jr., 1985 (1985.357.25) ornaments and talismans, the inscriptions of which provide an invaluable source of personal names and information about family relationships in that period.

The Kassite seals in the Museum are carved in valuable stones that were imported into Babylonia. ${ }^{2}$ They are inscribed with their owners' names, familial relationships, and the gods to whom they were devoted. It is notable that four of the sixteen seals belonged to women. Throughout the history of the ancient Near East, including the Kassite period, most seals were owned by men. Many also bear inscriptions that do not identify the owner's gender. The Museum's group of four Kassite women's seals represents a significant sample, constituting nearly a quarter of all women-owned seals from this period. ${ }^{3}$ Including these four, we know of seventeen seals that belonged to women out of the entire Kassite-period glyptic corpus. The Museum's four seals may therefore be treated as useful examples rather than as potential outliers. This article investigates the seals for insights that can be gained by examining the text together with the image on each seal. The article is thus a departure from previous analyses of the material, for those usually focus on either the text or the image over the other.
Cylinder seals from the Kassite period are inscribed in the cuneiform, or wedge-shaped, script that was used to write both the Sumerian and the Akkadian languages. Sumerian, the oldest written language, is a linguistic isolate unconnected to any other language, and by the mid-second millennium B.C., it was purely a written language. At that time, the lingua franca of Babylonia was Akkadian, a Semitic language related to such later languages as Arabic and Hebrew. The Kassites took their own language with them into Mesopotamia, but it is undocumented except for personal names and a disparate assortment of words. ${ }^{4}$ The majority of the inscriptions on the Museum's Kassite seals are written in Akkadian and feature a heavy use of Sumerograms, or cuneiform signs carrying logographic, rather than syllabic, readings. Determinatives are signs that are not vocalized but which provide information on the category of the word to which they are connected. For example, the divine determinative DIĜIR, written in transliteration as ${ }^{\mathrm{d}}$, indicates that the word immediately following it is the name of a deity. The inscriptions on the four seals of Kassite women in the Museum's collection identify their owners' gender by marking their
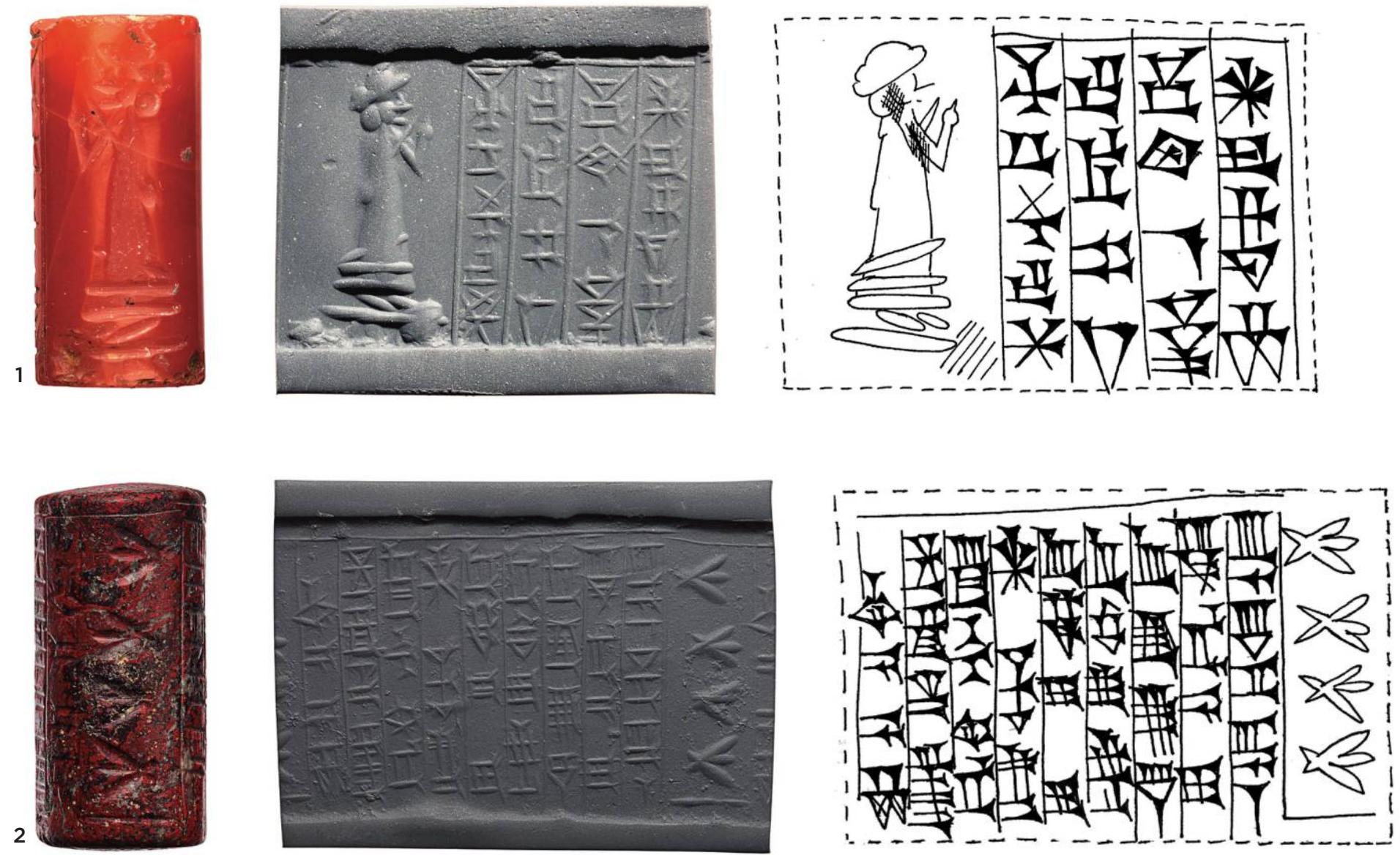
fig. 3 Cylinder seal of Naramtum with modern impression and line drawing. Carnelian, H. 1 in. $(2.5 \mathrm{~cm}$ ). The Metropolitan Museum of Art, Gift of The Right Reverend Paul Moore Jr. 1985 (1985.357.44)

fig. 4 Cylinder seal of Manbaši with modern impression and line drawing. Agate, H. $7 / 8$ in. $(2.3 \mathrm{~cm})$. The Metropolitan Museum of Art, Gift of Nanette B. Kelekian, in memory of Charles Dikran and Beatrice Kelekian, 1999 (1999.325.61)
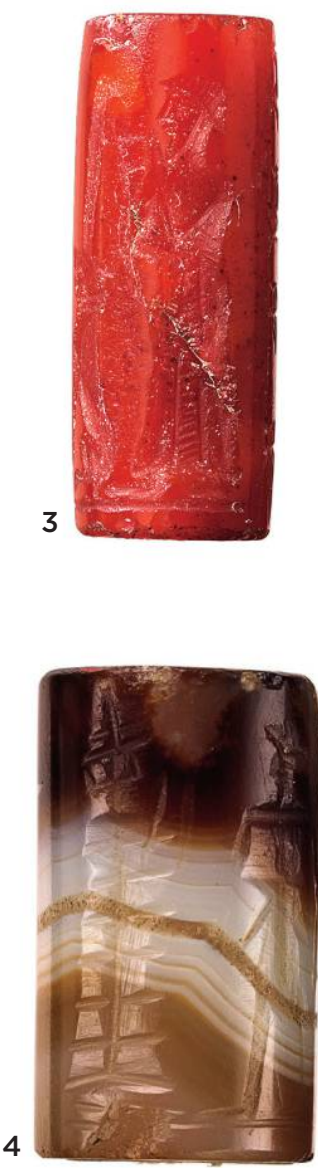

names with either the determinative munus, used exclusively for women, before their name, or by the word for female servant, $\operatorname{GEME}_{2} .{ }^{5}$ The names of the four women are Lamassani, servant of an unnamed deity (fig. 1); Kunnaiatum, whose seal is dedicated to the goddess Gula (fig. 2); Naramtum, servant of the divine couple Nergal and Mamitum (fig. 3); and Manbaši, servant of the divine couple Marduk and Șarpanitum (fig. 4). The inscriptions on these four seals vary in length and format. These seals, along with the rest of the group of sixteen at the Museum, are catalogued in the Appendix; the entries include their material, a transliteration and translation of their inscriptions, and a brief description of the image on each seal.

The Museum's sixteen seals are all stylistically representative of the First Kassite Style. Kassite glyptic art is traditionally separated into three categories: First, Second, and Third Style. First Style, the earliest, is often indistinguishable from the glyptic style of the Old Babylonian period, which preceded the Kassite. ${ }^{6}$ This style is easily identifiable, featuring one or more figures, most often human worshippers or divine figures, set beside an inscription presented in clearly divided vertical registers, both figure and inscription occupying the full height of the seal. Divine beings may be recognized by their typical horned headgear, and they are often larger and grander in physical stature than mortal figures depicted on the seals. The inscription is the clearest marker of the First Kassite Style. By far the most prevalent among the three seal types, we see nearly three times as many seals attributed to the First Style as to either the Second or the Third Style.

The four women-owned seals, while united in style, have fundamental differences, including the stone used for each, which provides information on the social status of the seal owners. The stones are carnelian (figs. 1, 3), jasper (fig. 2), and agate (fig. 4), semiprecious stones that had to be imported into Babylonia from elsewhere, often through the Persian Gulf. Furthermore, the seals of Lamassani and Naramtum (figs. 1, 3) are the only carnelian seals from the Kassite period in the Museum's collection. Carnelian, the product of long-distance trade with the Indus region, was especially prized in the ancient Near East, and carnelian ornaments are well represented among the grave goods of the so-called royal tombs of Ur dating to approximately $2600-2500$ B.C. ${ }^{7}$
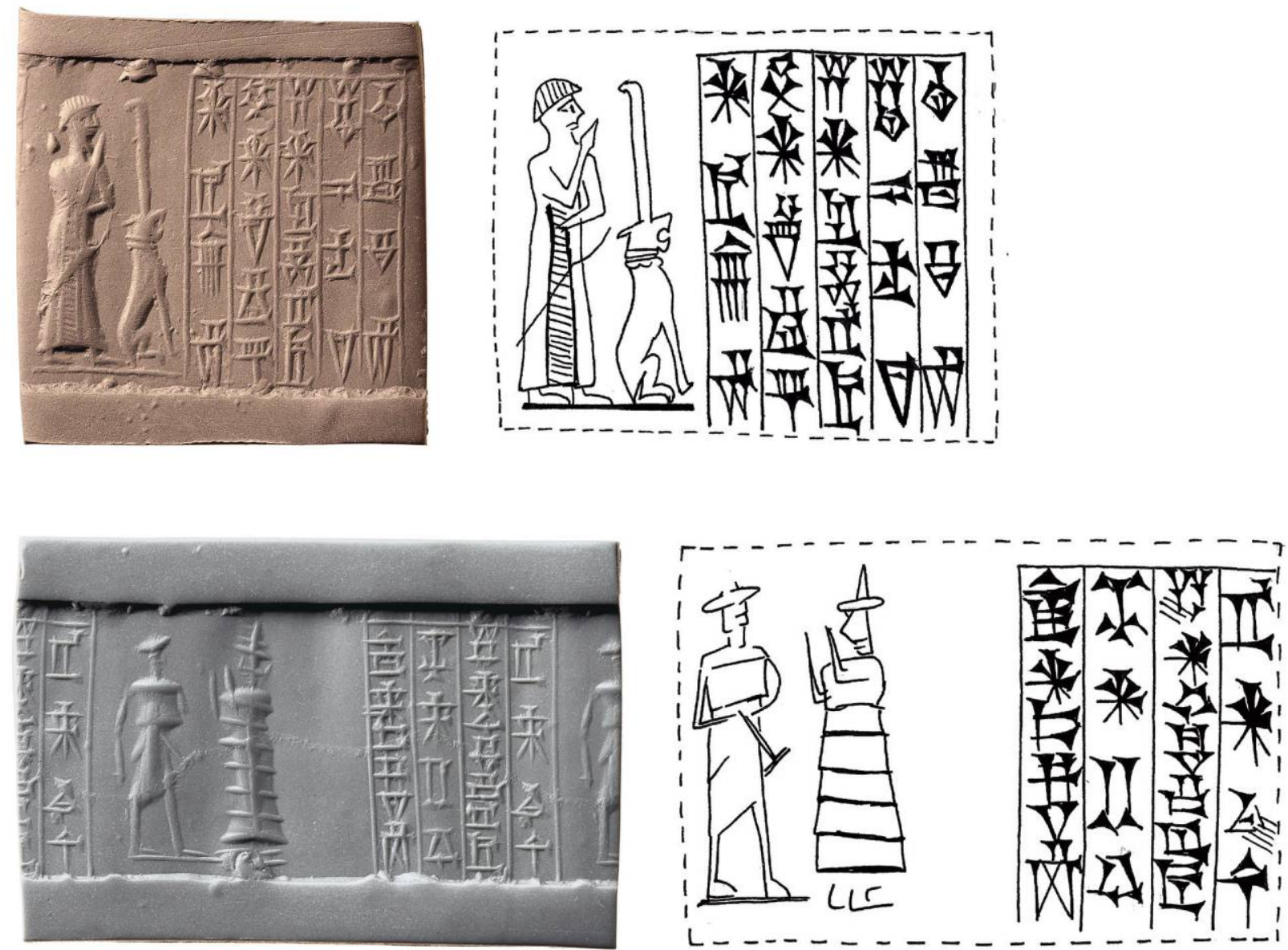
fig. 5 Cylinder seal of Tunamisah with modern impression and line drawing. Chalcedony, H. 111/16 in. $(4.3 \mathrm{~cm})$. The Metropolitan Museum of Art, The Cesnola Collection, Purchased by subscription, 1874-76 (74.51.4301)

fig. 6 Cylinder seal of Parga with modern impression and line drawing. Banded brown and white agate, $H .11 \frac{1}{8}$ in $(2.8 \mathrm{~cm})$. The Metropolitan Museum of Art, Gift of Georg Hahn, 1947 (47.115.1)

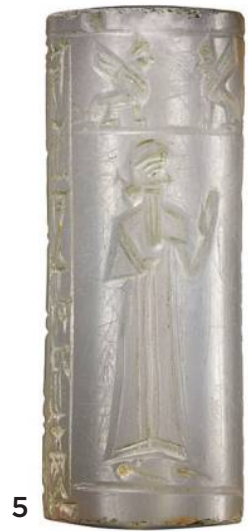

6

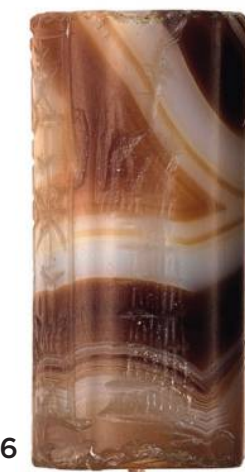

All the Kassite seals at the Museum with inscriptions that remain legible refer to deities of the Babylonian pantheon to whom the seal owner offered prayers and devotion. It is notable that all four of the women's seals are inscribed with the names of female deities. Two of the four are dedicated to divine couples: Nergal and his spouse Mamitum (fig. 3), and Marduk and his spouse Șarpanitum (fig. 4). In these instances, the male deity is by far the better known of the two. Nergal, who represented death and, more specifically, plague and pestilence, was invoked as protection against those ailments, and was usually represented as a striding male figure, often holding a mace. ${ }^{8}$ Regarding his consort Mamitum, we know little about the goddess save her connection to fate or oaths, indicated in the similar meaning of her name - the Akkadian word māmitu being translated as an oath or a vow-as she is seldom found independently of her spouse. Marduk, linked strongly with Babylon, his cult city, was a complicated deity who rose to power during the later second millennium B.C. and, in the first millennium B.C., headed the Mesopotamian pantheon. He was the central figure in several literary texts from Mesopotamia, including the Akkadian creation epic Enūma Eliš (When on High), which describes his defeat of the deified ocean, Tiamat, to establish the world and the ordered workings of the universe. The identity of his consort Sarpanitum is also closely tied to her far more famous spouse, and she had few independent appearances. References to her separately from Marduk indicate the specific importance put on the goddess in those instances. Although independent references to her are rarely seen in the Kassite period, in the first millennium B.C. she acquired greater independence. She had a shrine of her own at this time, located within Marduk's Esagil temple complex in Babylon, and the name of a processional way within the city invoked her name as the one who "made firm the base" of the king's throne. ${ }^{9}$

On the two women-owned seals that list only a female deity in their inscriptions, Sarpanitum appears without reference to Marduk on figure 1, and the goddess Gula appears on figure 2. Gula, the goddess of healing, is attested as early as the mid-third millennium B.C., gaining prominence from the Old Babylonian period onward. Linked to several male consorts, Gula was a prominent figure in incantations and was invoked for her abilities as a healer. ${ }^{10} \mathrm{Her}$ symbolic animal was the dog, a connection that was cited in textual and artistic sources from the second
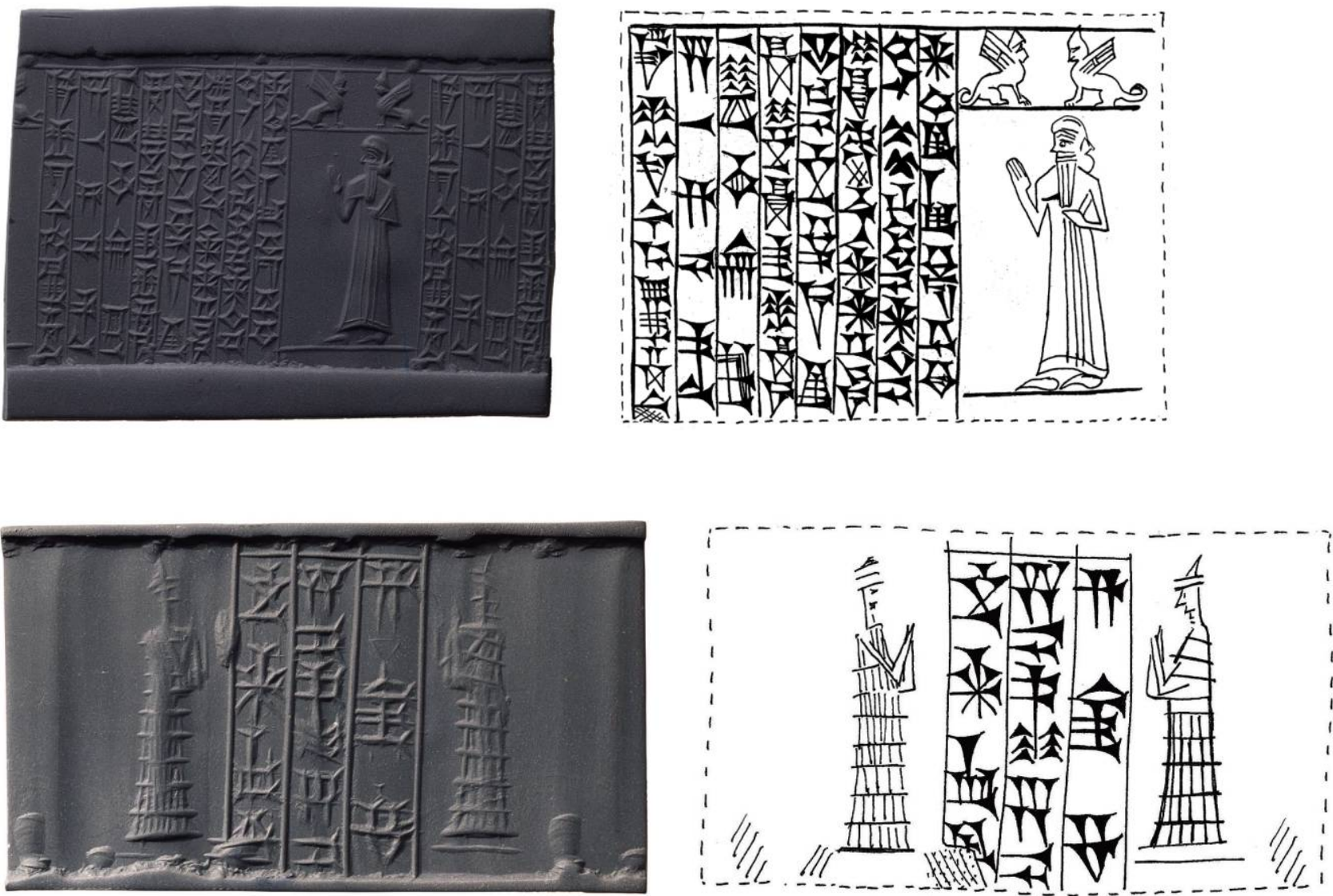

This content downloaded from 128.122.149.092 on December 15, 2018 05:37:02 AM All use subject to University of Chicago Press Terms and Conditions (http://www.journals.uchicago.edu/t-and-c). 
fig. 7 Cylinder seal of Nabû with modern impression and line drawing. Banded brown and white agate, $\mathrm{H} .7 / 8$ in $(2.2 \mathrm{~cm})$. The Metropolitan Museum of Art, Gift of Georg Hahn, 1947 (47.115.2)

fig. 8 Cylinder seal of Adadgamil with modern impression and line drawing Feldspar, H. $7 / 8$ in. $(2.2 \mathrm{~cm})$. The Metropolitan Museum of Art, Gift of Georg Hahn, $1947(47.115 .4)$
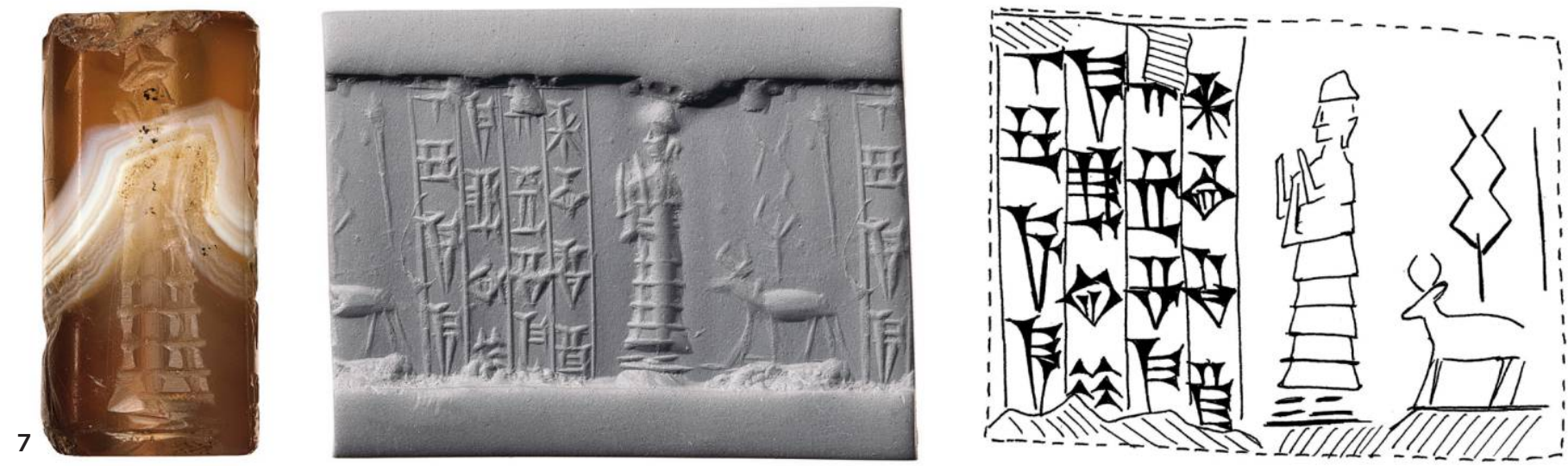

millennium B.C. onward. ${ }^{11}$ Although she also had a violent and destructive side, her most common titles focus instead on her healing qualities, and an early second millennium B.c. hymn to the goddess extols her soothing hands and her ability to heal wounds. ${ }^{12}$ These qualities are attributed to Gula in the Museum's seal's inscription (fig. 2), where she is described as "sparing," "merciful," and "preserving." With the goddess Gula very much the focus of the inscription, the name of the seal's owner, Kunnaiatum, seems nearly an afterthought on the seal. In fact, Kunnaiatum's name was fragmented, with the signs split into the last two lines of the inscription, suggesting that it is of less importance than the other text on the seal.

Neither Mamitum nor Șarpanitum shared the popularity of Gula, who was a well-known and widely represented deity. That Șarpanitum appears twice within this group of four seals, once with Marduk and once as an independent figure, suggests that she had a particular significance for women that seems at odds with her relatively infrequent depiction in other areas of Kassite art. The inscriptions of the four Kassite seals owned by women give clear emphasis to the power of female deities. In contrast, none of the seals in this group either owned by men or whose owner is unknown refers to divine couples. The divine pair of Šamaš and his consort Aya, for example, is represented on cylinder seals in the Museum's collection, ${ }^{13}$ but the Museum has none from the Kassite period. As with other divine pairs mentioned here, Šamaš, the sun god linked to justice and divination, was far more famous than Aya, but the goddess does have her own independent identity. ${ }^{14}$ As these two deities are attested on cylinder seals in periods that both precede and follow the Kassite, their absence within this group may be due only to chance.

There is also a pairing of two male deities on a Kassite seal at the Museum. In the inscription on the seal of Adad-gamil (fig. 8) - "Adad-gamil, Son of Raimkiti, Servant of Sîn and Amurru"-are the moon god Sîn and the god of the west, Amurru. Amurru's epithets often connect him to mountains, and the deity was both linked to and worshipped in particular by the Amorites, for whom Sîn was also an important deity, a fact that may explain the association of the two deities. ${ }^{15}$ Sin is by far the more prominent and widely represented of the two deities, who are often seen together
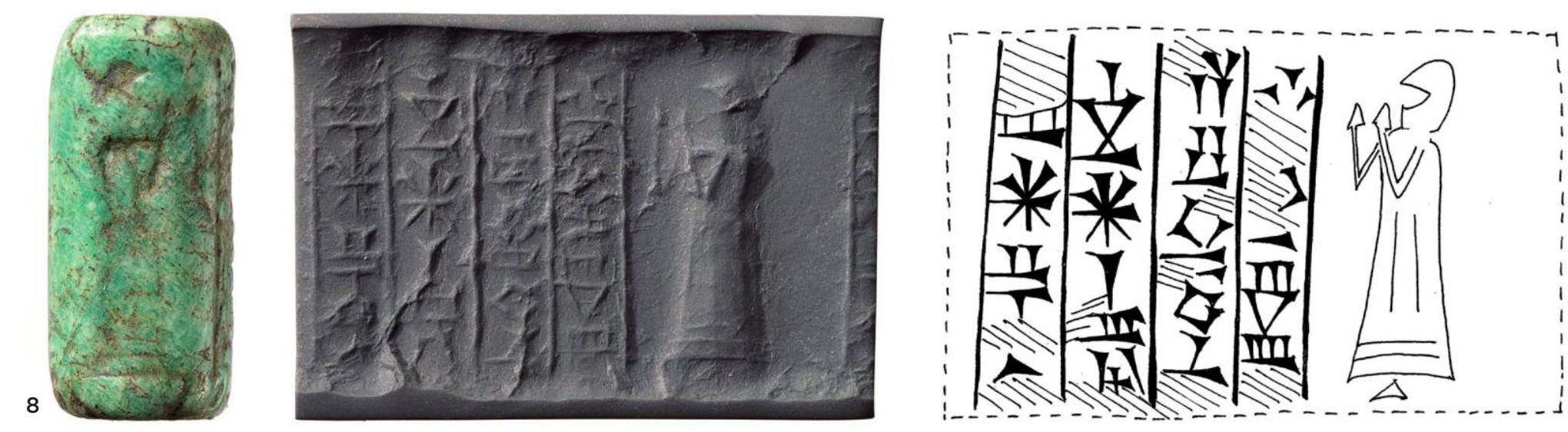
fig. 9 Cylinder seal with modern impression and line drawing. Faience, $\mathrm{H}$. 7/16 in $(1 \mathrm{~cm})$. The Metropolitan Museum of Art, Rogers Fund, 1956 (56.81.24)

fig. 10 Cylinder seal with modern impression and line drawing. Jasper breccia, H. $1 \frac{11 / 4}{4}$ in. $(3.2 \mathrm{~cm})$. The Metropolitan Museum of Art, Gift of Martin and Sarah Cherkasky, 1984 (1984.383.14)

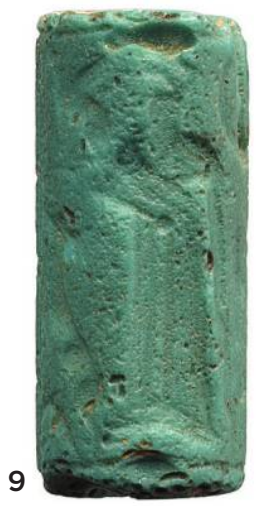

and even sometimes appear conflated, sharing iconographic attributes such as a curved staff or shepherd's crook ( $\mathrm{gamlu}) .{ }^{16}$ The deities are also together on cylinder seals in the earlier Old Babylonian period, and the connection continues into the first millennium B.C., with the two invoked as a connected figure in a major incantation series against witchcraft. ${ }^{17}$ The appearance of the two deities together in the inscription on the seal of Adad-gamil is thus in keeping with what is, by the Kassite period, fairly well established practice.

Among the twelve Kassite seals at the Museum that were owned by men or whose owner's gender is unknown, only one (fig. 11) names a female deity, Inanna, a goddess who crossed boundaries and was undoubtedly the most powerful female deity in Mesopotamia: "O Inanna of Agade, / The lady who embraces the rites of heaven and earth, / Your speech, your lordly gaze, / [On] Nur-Šamaš, your servant, / Look truly, look favorably [upon him]. / May he acquire wealth, may he acquire abundance. / May those days be bright. / May those joyful thoughts be established."

This long inscription is a prayer for Inanna's favor and extols her virtues and powers, asking her to secure the good fortune of Nur-Šamaš, the seal's owner.
Though Nur-Šamaš's name is more carefully integrated into the prayer than is Kunnaiatum's on her seal (fig. 2), the text of both seals demonstrates the same essential intent. Both seal owners lavishly praise a goddess, hoping to ensure her benevolent attention through the means of dedicating an important, precious personal object to her. Inanna was one of the most prominent Babylonian deities, making her worthy of Nur-Šamaš's prayers. The goddesses that appear on the other seals owned by men within the Museum's Kassite group do not receive such detail. We cannot say whether this is because of a perceived affinity between goddesses and their female worshippers that did not extend to male worshippers, or whether it is a result of lower esteem for female deities among men in Kassite Babylonia, or other possible reasons.

The imagery on several of the cylinder seals complicates the picture of direct female identification between the seal owner and the deity named in the inscription. Although the four seals belonging to women all refer to female divine figures in their inscriptions, only one depicts exclusively female imagery, the seal of Lamassani (fig. 1), dedicated to Șarpanitum. On this seal, a supplicant figure with upraised hands,
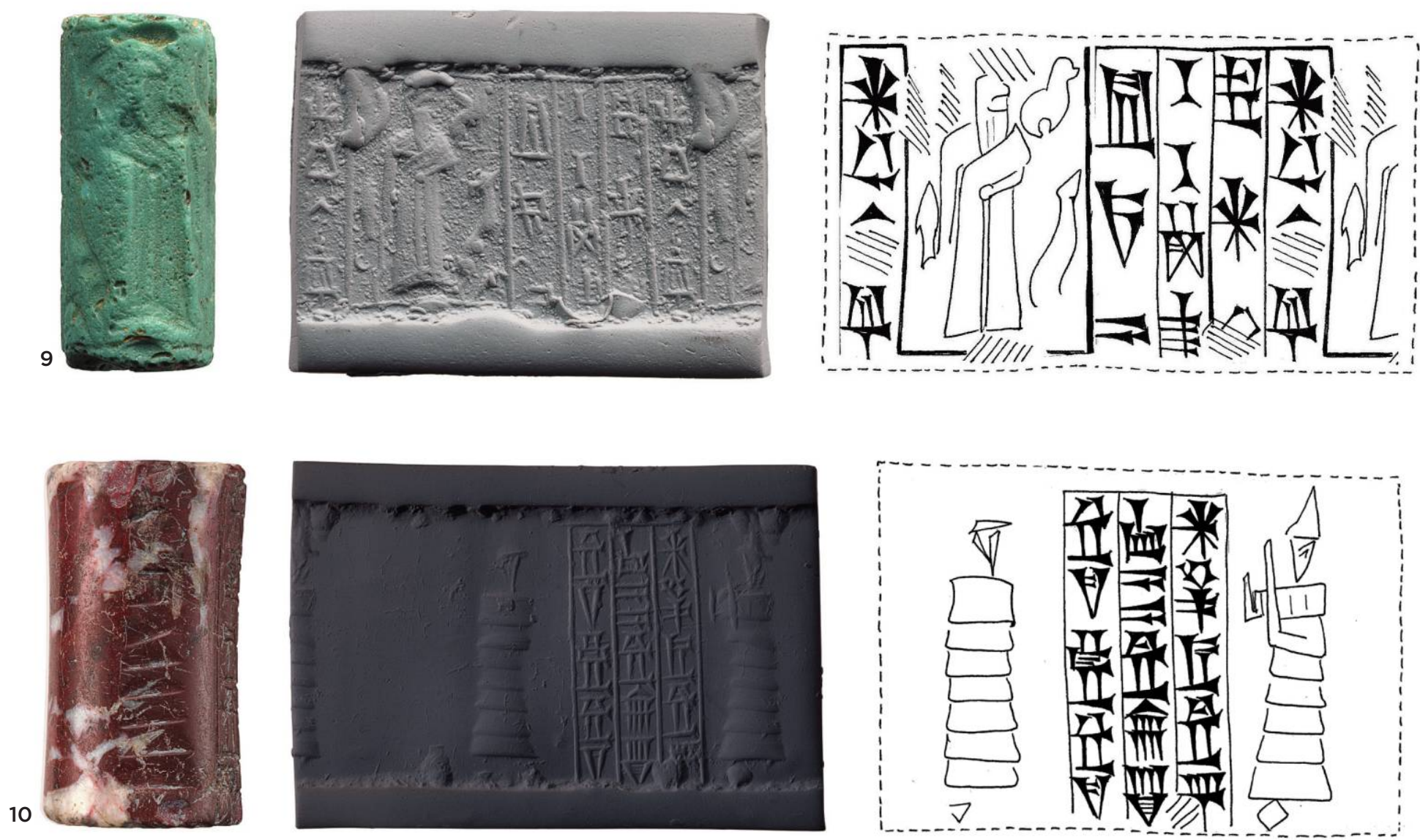

This content downloaded from 128.122.149.092 on December 15, 2018 05:37:02 AM All use subject to University of Chicago Press Terms and Conditions (http://www.journals.uchicago.edu/t-and-c). 

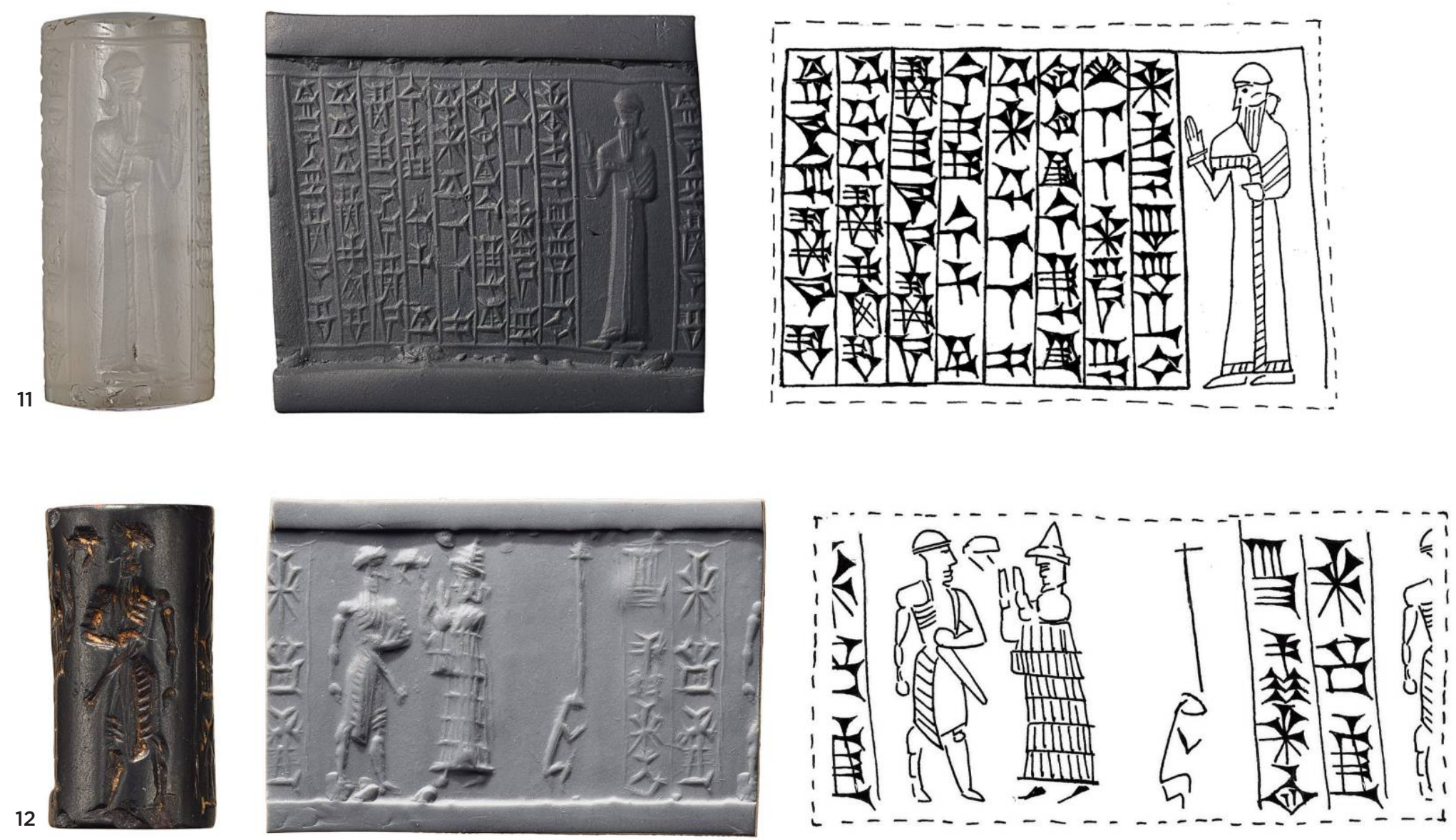

fig. 11 Cylinder seal of NūrŠamaš with modern impression and line drawing. Milky chalcedony, H. $13 \%$ in.

$(3.4 \mathrm{~cm})$. The Metropolitan Museum of Art, Gift of The Right Reverend Paul Moore Jr., 1985 (1985.357.29)

fig. 12 Cylinder seal with modern impression and line drawing. Hematite, H. 1 in. $(2.4 \mathrm{~cm})$. The Metropolitan Museum of Art, Gift of Nanette B. Kelekian, in memory of Charles Dikran and Beatrice Kelekian, 1999 (1999.325.56)

wearing a long robe with an elaborate hem, is shown in profile. She wears a headdress and her hair is gathered in a round mass at the nape of her neck. The image of the supplicant goddess, or protective Lama figure, appears frequently in the Kassite period. A stele from Uruk dating to this period, also in the Museum's collection (fig. 15), depicts a supplicant goddess in profile, hands upraised, with divine headdress and long robe. The stele's inscription on her tiered robe reinforces her role as a protective figure, indicating it was dedicated for the life of the Kassite ruler Nazi-Maruttaš. ${ }^{18}$

The seal of Kunnaiatum (fig. 2), dedicated to Gula, features imagery that is not distinguishable as either male or female. Instead, we see the nine lines of the seal's inscription bordered by a column of four fly-like objects. From the early second millennium B.C. onward, flies are represented on cylinder seals as simply a pair of crossed wedges; earlier seals also depict them, though more rarely, as fully detailed and truer to life. ${ }^{19}$ In addition, flies are represented in texts with connections to the gods. In the Epic of Gilgamesh, arguably Mesopotamia's most famous literary text, the mother goddess Bēlēt-ilī clutches a necklace of flies, swearing that she will never forget the flood that the gods inflicted upon mankind. ${ }^{20}$ There are also necklaces from the Royal Tombs of Ur that were strung with fly pendants among their gold, lapis lazuli, and carnelian beads, in an earlier echo of this literary motif. ${ }^{21}$

On the seal of Manbaši (fig. 4), dedicated to Marduk and Șarpanitum, there is prominent masculine imagery. One of the figures, clearly male, bears a weapon, most likely a mace. The figure of a man holding a mace is well represented on cylinder seals from earlier periods, particularly in the Old Babylonian period, and it was often accompanied by a supplicant Lama figure. While the male figure may occasionally be identified as a deity, he most often lacks visible markers of divinity such as a horned headdress. Instead, he is usually presented as a king, a position that is either inferred from the visual iconography in his representation or revealed directly in the seal's inscription when there is one. In seals from the Old Babylonian period, the figure of a "king with a mace" appears particularly on ones that belonged to individuals who had significant social or bureaucratic standing. ${ }^{22}$

The seal of Naramtum (fig. 3) illustrates another level of complexity in which specific deities' names 
fig. 13 Cylinder seal with modern impression and line drawing. Rock crystal, H. $7 / 8$ in. $(2.3 \mathrm{~cm})$. The Metropolitan Museum of Art, Gift of Nanette B. Kelekian, in memory of Charles Dikran and Beatrice Kelekian, 1999 (1999.325.58)

fig. 14 Cylinder seal of Šumanum with modern impression and line drawing. Hematite, H. 11/16 in. $(2.7 \mathrm{~cm}$ ). The Metropolitan Museum of Art, Gift of Nanette B. Kelekian, in memory of Charles Dikran and Beatrice Kelekian, 1999 (199932560) are juxtaposed with imagery associated with other deities. The inscription on the seal of Naramtum names the gods Nergal and Mamitum, yet the image shows a male worshipper in profile behind a seated dog, the animal closely affiliated with the healing goddess Gula. The polelike element rising from the dog's head indicates that it is not a living creature but is instead a divine manifestation or a piece of temple statuary, such as the guardian lions paired in front of many Babylonian temples. Although Nergal was the god of plague and pestilence, he also protected against these ailments, and his appearance in the seal's inscription could be considered to be reinforced by the presence of Gula. The composition is deliberate, with text and image intended as a coherent whole, for none of the seals in this group of sixteen shows evidence that inscriptions were added after the seal's initial carving or that images were recarved at a later date. It is difficult now to see how Nergal and Mamitum, their female devotee Naramtum, and a male worshipper approaching a dog of Gula were connected, but the entire composition undoubtedly communicated important aspects of the owner's family and religious affiliations.
The inscriptions on the four seals owned by women are among the most elaborate of those on the Museum's group of sixteen Kassite seals and are here considered alongside the detailed imagery also present on the seals. The inscriptions focus on divine figures and the lineage of the female owners rather than providing information about these women as individuals, but the extensive length and complexity of the inscriptions indicate that the owners occupied an elite position in the society of Kassite Babylonia. It is not known whether these seal owners actually used their seals as administrative tools or whether the seals were intended primarily as personal ornaments. Women did not, by and large, occupy the economic and legal roles that would require them to impress their own personal seals on such documents, a common use of cylinder seals that belonged to men. ${ }^{23}$ In order to begin to contribute to our understanding of aspects of this important but little-documented period in Babylonian history, we must consider the texts and images on these seals as part of a coherent whole, as did the artisans who made them and the Kassite women for whom they were made. Though we do not know to what extent the owners of the seals specified materials, inscriptions, and
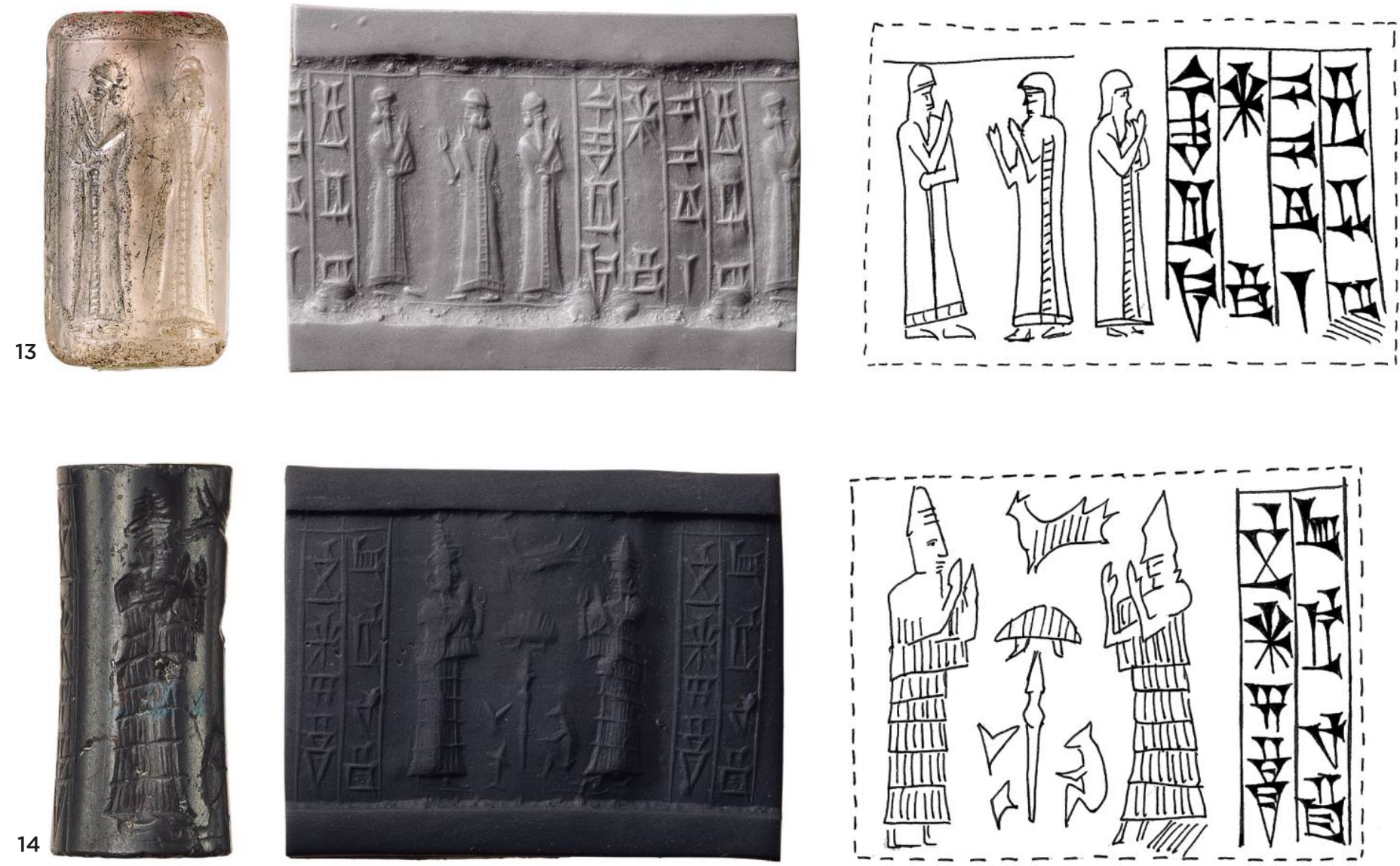

This content downloaded from 128.122.149.092 on December 15, 2018 05:37:02 AM All use subject to University of Chicago Press Terms and Conditions (http://www.journals.uchicago.edu/t-and-c). 
fig. 15 Stele of the protective goddess Lama. Kassite period, ca. 1307-1282 B.C southern Mesopotamia, Uruk. Gypsum alabaster; $33 \times 12 \times 8$ in. $(83.8 \times 30.5 \times$ $20.3 \mathrm{~cm}$ ). The Metropolitan Museum of Art, Gift of E. S. David, 1961 (61.12)

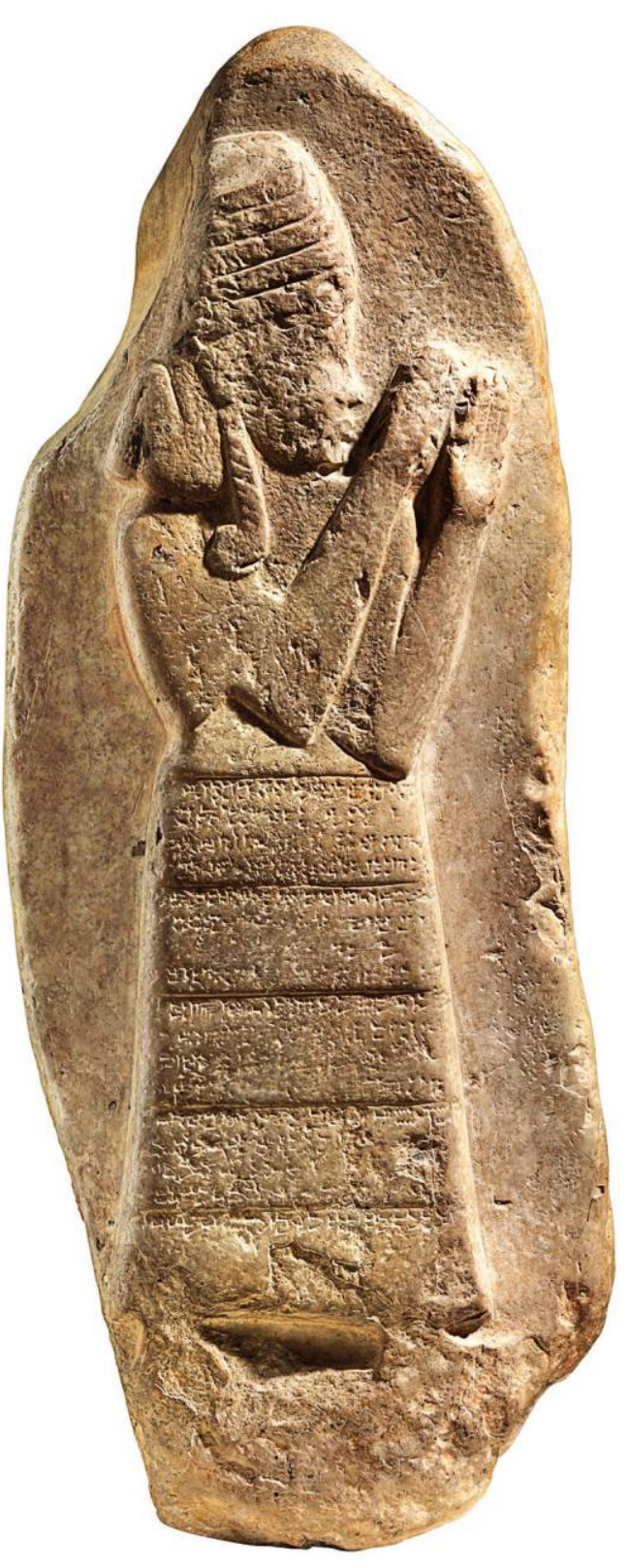

imagery, both the textual and the visual elements of each seal were selected deliberately and thoughtfully with the intent that they work together to convey meanings of individual significance.

\section{ACKNOWLEDGMENTS}

I completed the initial catalogue and drawings of the Kassite cylinder seals during my time as a fellow in the Department of Ancient Near Eastern Art at the Metropolitan Museum. I am grateful for assistance from members of the department on both the catalogue and the early drafts of this article, particularly Sarah Graff and Elizabeth Knott, and to the department as a whole for giving me access to the files on these seals, which include important notes and comments by Edith Porada.

\section{GINA KONSTANTOPOULOS}

Postdoctoral Researcher, Faculty of Theology, University of Helsinki 


\section{Catalogue of the Inscribed Kassite Cylinder Seals in The Metropolitan Museum of Art}

Beyond the broad identification of the Kassite period and First Kassite Style to which these sixteen cylinder seals all belong, no specific date can be attributed to any one. For several seals, particularly MMA 47.115.1-.4, the style blurs with that of the late Old Babylonian, and thus even this dating is not absolute. The seals are listed in order of their date of accession; MMA 47.115.1-.4 represent the only clearly connected group of seals in the catalogue.

\section{A NOTE ON THE TRANSLITERATION OF INSCRIPTIONS}

The cuneiform inscriptions on these seals were inscribed vertically within clearly defined registers over the full height of the seal. When the seals were rolled onto damp clay, the text they inscribed was read from top to bottom and from right to left. The majority of the inscriptions are written in Akkadian and feature the heavy use of Sumerograms, or cuneiform signs carrying logographic, not syllabic, meanings that align to Sumerian words. The few inscriptions that are entirely in Sumerian are transliterated in expanded spacing, as seen in the first lines of MMA 74.51.4301 (fig. 5), for example, to differentiate the language employed, according to standard Assyriological practices. Generally, Akkadian is transliterated or transcribed in italics, while Sumerograms within an Akkadian text appear in small caps. Regarding other conventions of transliteration, superscript is generally used to indicate determinatives, signs that are not vocalized but provide information on the category of the word to which they are connected. On the seals here, the divine determinative DIĜIR is most often seen written simply as ${ }^{\mathrm{d}}$. Other common determinatives and their meanings include munus before a female name; diš before a male name; ${ }^{\text {na4 }}$ to indicate stone; and ${ }^{\mathrm{ki}}$, which follows a word, to indicate a location or place.

Cuneiform signs have phonetic as well as logographic readings, and, particularly when a line is fragmentary, signs may be read as phonetic values without their meanings being able to be understood or interpreted. Since most cuneiform languages, including Sumerian and Akkadian, are polysemic, with a particular sign having several possible phonetic readings, the correct reading is tied closely to the meaning of the sign in its particular context. Thus it is difficult to write an accurate transliteration in either Sumerian or Akkadian when the translation is unclear. In these circumstances, the most common phonetic value of the sign is written in lowercase without alterations, to indicate the sign that is present but that its meaning could not be accurately determined (as in MMA 47.115.2, MMA 47.115.3, MMA 1999.325.58). If the sign is entirely unclear and cannot be read at all, an $\mathrm{x}$ is used to indicate the presence of a sign that cannot be deciphered.

MMA 74.51.4301 (fig. 5)

The seal image shows, in fine detail, a standing bearded male supplicant figure wearing a fringed robe. He faces the eight-line inscription with his right hand raised. Above him, in a register set off by a dividing line, two sphinxes crouch facing each other. Chalcedony, H. $1^{11 / 16}$ in. $(4.3 \mathrm{~cm})$
The Cesnola Collection, Purchased by subscription, $1874^{-76}$ Inscription:

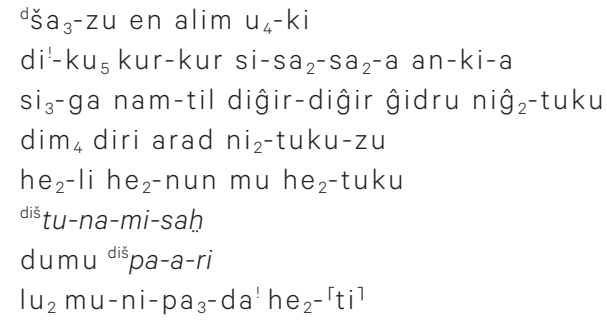

Marduk, the lord, the bull, the light of the land

The judge of all the lands,

[who] sets right [all] in

heaven and earth,

Giver of life [to] the gods,

[who] holds the scepter,

Exceedingly great,

your reverent servant,

May he be lustrous, may he

be princely, may [his] name

endure.

Tunamisah,

Son of Pāri,

The one called forth by

name; may he prosper!

Comment: The use of the epithet of dša ${ }_{3}-\mathrm{zu}$, "knows the heart," for Marduk is later seen in the fifty names of Marduk listed in Enūma Eliš VII:35 and is repeated in several other cylinder seal inscriptions as well as within larger texts. ${ }^{24}$ The fine detail in carving is observed in all aspects of the seal-the bearded figure, the two sphinxes, and the inscription itself-and sets it apart from MMA 47.115.1-.4.

This cylinder seal entered the Museum's collection in 1874, well before the other seals discussed here, giving it the oldest publication history of the group.

Publications: Sayce 1877, pp. 441-43; Ward 1895, nos. 391-96; Price 1908, no. 6; Ward 1910, pp. 185-86; Limet 1971, no. 6.3; Imai 1983, no. 132; Paulus 2014, p. 182n 331

MMA 41.160.314 (not illustrated)

On this badly worn seal, a figure wearing a long fringed robe faces a seven-column inscription that is illegible except for various signs.

Chalcedony, H. $1^{1 / 8}$ in. $(2.8 \mathrm{~cm})$

Bequest of W. Gedney Beatty, 1941

Comment: The seal is First Kassite Style, with a single figure facing the inscription in a manner similar to MMA 1985.357.29. It is worn and broken along the top edge of the seal; the upper torso, shoulders, and head of the figure are missing.

MMA 47.115.1 (fig. 6)

Two supplicant figures stand with hands raised; they wear horned headdresses and flounced robes. The figures flank a threecolumn inscription with their hands raised toward it, as if praising both the inscription and the individual it names. 
Banded brown and white agate; H. $1^{1 / 8}$ in. $(2.8 \mathrm{~cm})$

Gift of Georg Hahn, 1947

Inscription:

pa-ar-ga?

DUMU a-ge-ya

ARAD ${ }^{\mathrm{d}}$ EN.ZU

Parga,

Son of Ageya,

Servant of Sîn

Comment: The names of the two individuals on this seal, Parga and Ageya, are attested in sources from the period, although both, particularly the former, are uncommon personal names. Parga is also attested in the corpus of Akkadian letters found at Ras Shamra as a topographical name that is clearly unconnected to the individual who appears in this inscription. ${ }^{25}$ The second name, Ageya, is attested more frequently than Parga, most often appearing as a patronymic. ${ }^{26}$

Publication: Lilyquist 1994, pp. 16-18, 35-36

MMA 47.115.2 (fig. 7)

A supplicant figure with raised hands, wearing headdress and tiered robe, stands facing the initial line of a four-line inscription. Behind the figure is the symbol of the storm god Adad/Iškur, a lightning fork on the back of a standing bull.

Banded brown and white agate; H. $7 / 8$ in. $(2.2 \mathrm{~cm})$

Gift of Georg Hahn, 1947

Inscription:

${ }^{\mathrm{d}}$ na-bi-um

[DUMU]?.SAG BI.GAL

TUKU.NIR di še

ME AB.TUKU.TUKU

Nabû,

... The foremost son,

Authoritative...

Possessing all the rites.

Comment: Although the signs on this seal are clear, the meaning of the middle two lines is uncertain. The initial sign in the second line is only partially preserved, and although traces of a vertical may be interpreted, the reading of DUMU.SAĜ, or "firstborn or foremost son, the eldest," is more intelligible than "PA SAĜ," the other possible reading of the initial two signs in that line. ${ }^{27}$ The use of DUMU. SAĜ on seals is relatively infrequent, however, and is very rarely seen in texts as a whole after the Old Babylonian period, which may push the dating on this seal earlier into the transitional and early periods most often represented in seals of the First Kassite Style. ${ }^{28}$ Publication: Lilyquist 1994, pp. 16-18, 35-36

MMA 47.115.3 (fig. 1)

A supplicant figure with raised hands, wearing a headdress and long robe, stands and faces the closing line of a four-line inscription. The robe ends at the hem in a distinctive wide double border.

Carnelian, H. $7 / 8$ in. $(2.2 \mathrm{~cm})$
Gift of Georg Hahn, 1947

Inscription:

${ }^{\mathrm{d}}$ șar'-pa-ni-tum

NIN ŠA $\mathrm{A}_{3} L \mathrm{~L}_{2} \cdot \mathrm{SU}_{3}$

la-ma-sà-ni

$\mathrm{GEME}_{2}$ uh? la an

Șarpanitum,

Merciful lady,

Lamassani,

Female servant of ...

Comment: Lamassani is a name seen primarily in the context of naditu women from Sippar in the Old Babylonian period, a context that lists six different women with this name..$^{29}$ Sarpanitum, consort of the god Marduk, is a far less-well-known deity than her more famous spouse, and she rarely appears independently of him. The final line of this seal is problematic: the middle sign is partially obscured and may be traces of an "uh" sign, though this does not resolve into any common name. Other potential reconstructions of the sign are similarly unhelpful. Lacking other possibilities or options, I follow W. G. Lambert's initial comment that "the title is a mystery," and may well be an illegible royal name, in lieu of an illegible divine one. ${ }^{30}$

Publication: Lilyquist 1994, pp. 16-18, 35-36

MMA 47.115.4 (fig. 8)

A supplicant figure wearing a robe, bordered near the bottom edge, stands with hands raised, facing a four-line inscription. The inscription and the figure are both badly worn.

Feldspar, H. $7 / 8$ in. $(2.2 \mathrm{~cm})$

Gift of Georg Hahn, 1947

Inscription:

d[I]M ga-mi[l]

DUMU ra'-im-ki-ti

ARAD ${ }^{d}$ EN.ZU

$\Gamma_{\dot{U}}{ }^{\top} \mathrm{d}$ MAR.TU

Adad-gamil,

Son of Raimkiti,

Servant of Sîn

And Amurru.

Comment: The name of this individual, Adad-gamil, is clear despite the somewhat obscured signs, though the most prominent other attestation of this name is found in agricultural texts from Mari dated to the reign of Zimri-Lim..$^{31}$ His father's name, though more unusual, is attested from the Temple Archives at Nippur. ${ }^{32}$

Publication: Lilyquist 1994, pp. 16-18, 35-36

MMA 56.81.24 (fig. 9)

The male figure wears a long robe and holds a scimitar; there is a fish behind him. In front of the figure's lower body is a rearing animal, with another animal crouching at the height of his head. The figure faces toward the final line of a four-column inscription. Faience, H. $7 / 16$ in. $(1 \mathrm{~cm})$

Rogers Fund, 1956 
Inscription:

dutu [umun]-gal

saĝ an $[k i]$

bad-bad he $e_{2}$-nun

arhuš tuku-a

[The god] Šamaš, the great lord,

Foremost [in] heaven and earth,

Revealing plenty,

[The one] who is compassionate.

Comment: Although many of the Kassite seals are written in Sumerogram-heavy Akkadian (with often only the inclusion of personal possessive markers in phonetic Akkadian), this seal is entirely in Sumerian, without even the personal name of the owner. Instead it is focused upon and dedicated entirely to the invoked deity. The seal's inscription is fairly straightforward, with the exception of the third sign in the first line: the traces clearly suggest a large winkelhaken, or single hook-shaped sign, as the only sign present. The only possible reading of " $u$ " here would be umun, the Emesal reading for en, or lord. In Kassite seals, the equation of " $u$ " for "umun" is also well attested. The presence of Emesal, a dialect of Sumerian most often used in ritual texts, in cylinder seal inscriptions is not unattested, and we see similar readings of umun elsewhere, from locations both inside and outside Mesopotamia. ${ }^{33}$ Publication: Herzfeld 1923-46, no. 2893

MMA 1984.383.14 (fig. 10)

A supplicant female figure with hands raised and another female figure flank a three-line inscription; the space around each of the figures is otherwise undecorated. Part of a gold mount is lodged in the hole of the cylinder seal.

Jasper breccia, H. $1^{1 / 4}$ in. $(3.2 \mathrm{~cm})$

Gift of Martin and Sarah Cherkasky, 1984

Inscription:

dim ur-sag-gal

en a-a saĝ-giga-ga

saĝ-ni ezen? saĝ-ni

Adad, the great warrior,

The lord, the father of the black-headed people,

His servant ... his servant

Comment: The term "black-headed people" (sa $\hat{g}$ - $\operatorname{gig}_{2}$-ga) is used to refer to the inhabitants of Mesopotamia as late as the Neo-Assyrian period. It does not appear to be linked to an ethnic group or a particular subset of people within Mesopotamia, but is instead used without distinction for those within the borders of Mesopotamia. ${ }^{34}$ Lacking a personal name, this cylinder seal falls into the same group as the previous cylinder seal in that its focus is exclusively on the deity, in this case the storm god Adad/Iškur. Publication: Pittman and Aruz 1987, no. 36

MMA 1985.357.25 (fig. 2)

Four fly-like objects lie in a row next to nine lines of inscription.

Jasper, H. $1^{1 / 2}$ in. $(3.9 \mathrm{~cm})$
Gift of The Right Reverend Paul Moore Jr., 1985

Inscription:

e-tè-e-rum

ga-ma-a-lu

šu-zu-ú-bu

šu-ul-Iu-mu

šu-uk?-lu-lu

${ }^{\mathrm{d} g u-l a}$

ša ti-di-ma

${ }^{\mathrm{NA} 4} \mathrm{KIŠ} I \mathrm{~B}$ munus $k u-u n-$

na-a-a-tum

Sparing,

Merciful,

Preserving,

Completing,

Perfecting,

Gula,

[All] that you know;

The seal of Kunnaiatum.

Comment: The most minimalistic of the Kassite seals, MMA 1985.357.25 is the only seal in this group without a figural drawing in addition to its inscription, and the only seal that is predominantly in Akkadian, with just the exception of the Sumerograms in the penultimate line. In regard to the fly-like objects that accompany the seal's inscriptions, we can compare them to similar flies on Kassite seals at the Musée du Louvre, Paris, and the Morgan Library and Museum, New York. ${ }^{35}$ The long Akkadian inscription on this seal features the unusual sectioning of the owner's name, Kunnaiatum, in its two final lines. Given the vertical arrangement of the seal's composition, along with the length of Kunnaiatum's name, this seems a planned layout-corroborated by the indentation of the final line of the inscription.

Publications: Eisen 1940, no. 70; Metropolitan Museum 1985, p. 16

MMA 1985.357.26 (not illustrated)

Two male figures on this seal face a five-line inscription that is no longer legible. Both figures wear caps and long, fringed robes and hold staves or crooks in their right hand, with their left arm bent across their chest. A vertical arrangement of three reclining animals, likely ibex, separates the two figures.

Microline feldspar, H. $13 / 8$ in. $(3.5 \mathrm{~cm})$

Gift of The Right Reverend Paul Moore Jr., 1985

Comment: This seal displays all the hallmarks of the First Kassite Style. The figures holding a staff or crook in their hands are similar to representations of the god Ninšubur that are seen in this period. ${ }^{36}$

Publications: Eisen 1940, no. 69; Metropolitan Museum 1985, p. 16

MMA 1985.357.29 (fig. 11)

A solitary male bearded figure in a long fringed robe stands with right hand raised, facing an eight-line inscription in even registers.

Milky chalcedony, H. $13 / 8$ in. $(3.4 \mathrm{~cm})$

Gift of The Right Reverend Paul Moore Jr., 1985 
Inscription:

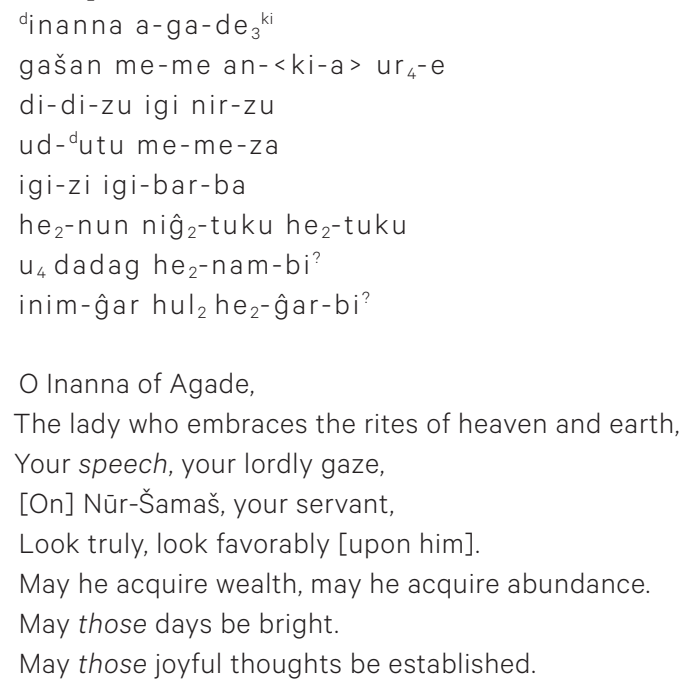

Comment: The goddess referred to in the opening lines of this inscription is the particular representation of Inanna linked to the ruling kings of the Sargonic period (ca. 2234-2113 B.C.) and their capital city of Agade. ${ }^{37}$ As a personal name, Nūr-Šamaš is attested multiple times in the Kassite period. ${ }^{38}$ The third line of this seal is unquestionably the most difficult to interpret, but the Sumerian di-di has lexical equivalents with the Akkadian words dabābu and $a t m \hat{u}$, both of which may be translated as speech or utterance. Publications: Eisen 1940, no. 68; Limet 1971, no. 6.13;

Metropolitan Museum 1985, p. 16

MMA 1985.357.44 (fig. 3)

A male worshipper wearing a round cap faces the closing line of a five-line inscription. In front of the figure is a seated dog surmounted by a standard, a common motif of the goddess Gula. Carnelian, H. 1 in. $(2.5 \mathrm{~cm})$

Gift of The Right Reverend Paul Moore Jr., 1985

Inscription:

na-ra-am-tum

DUMU.munus a-hu-ni

DUMU da-gan-ma-lik

$\left.\mathrm{GEME}_{2}{ }^{\mathrm{d}} \mathrm{NE}_{3} \cdot \mathrm{IR}\right|_{11}$ GAL

dma-mi-tum

Naramtum,

The daughter of Ahuni,

Son of Dagan-Malik,

Servant of [the god] Nergal

[and the goddess] Mamitum

Comment: Ahuni was a popular name, with notable individuals having held it, including a cupbearer of the Ur III ruler Šu-Sîn. ${ }^{39}$ It appears linked to less renowned individuals on other cylinder seals and is widely attested during the Kassite period..$^{40}$ Mamitum is rarely attested except when she is paired with her spouse, the god Nergal, deity of plague, pestilence, and warfare..$^{41}$ Publication: Metropolitan Museum 1985, p. 16
MMA 1999.325.56 (fig. 12)

A male figure, possibly divine, wearing a round cap and a short fringed garment, stands holding a mace (or short staff) at his waist. Facing him is a figure wearing a long fringed robe and pointed cap; he has both hands raised in supplication. A monkey surmounted by a standard crouches behind the second figure. To the right of the monkey is a two-column inscription.

Hematite, H. 1 in. $(2.4 \mathrm{~cm})$

Gift of Nanette B. Kelekian, in memory of Charles Dikran and Beatrice Kelekian, 1999

Inscription:

${ }^{d}$ nin-šubur

sukkal zi-an-na

Ninšubur,

True vizier of An.

Comment: We see this inscription repeated in the first two lines of a late Old Babylonian/Early Kassite seal at the Morgan Library and Museum. ${ }^{42}$ The two-line inscription is repeated exactly on a worn seal of similar style, also at the Morgan Library and Museum..$^{43}$ By the Kassite period, Ninšubur has merged with the figure of Papsukkal, and absorbed the latter's close connections with Anu, as opposed to his role and connection to the goddess Inanna. Given Ninšubur's recognizable iconography as a god bearing a staff, the figure bearing a weapon, which is either a mace or short staff, on the present cylinder seal may represent this deity. Publication: Metropolitan Museum 1999

MMA 1999.325.58 (fig. 13)

A bearded male worshipper and a non-bearded worshipper face each other, both wearing caps and long fringed robes. The figure with the beard raises his right hand and the other raises both his hands. Another bearded worshipper stands to the right, facing the closing line of the four-line inscription, his right hand raised. Rock crystal, H. $7 / 8$ in. $(2.3 \mathrm{~cm})$

Gift of Nanette B. Kelekian, in memory of Charles Dikran and Beatrice Kelekian, 1999

Inscription:

ab ud ma

$a-a-b a-a s ̌$

${ }^{d}$ mes

igi-<tab >-a-ni arhuš tuku

Abaš,

Marduk,

His gaze bears mercy

Comment: This inscription's poorly preserved initial line is difficult to read and translate.

Publication: Metropolitan Museum 1999

MMA 1999.325.60 (fig. 14)

Two figures, possibly divine, stand with both hands raised in supplication. They flank a staff (or spear), which is surmounted by a hedgehog. A goatfish is above the hedgehog, and a fly, a fish, 
and a monkey are arrayed beside the staff. There is a two-line inscription.

Hematite, H. $1^{1 / 16}$ in. $(2.7 \mathrm{~cm})$

Gift of Nanette B. Kelekian, in memory of Charles Dikran and Beatrice Kelekian, 1999

Inscription:

šu-ma-nu-um

ARAD $\mathrm{d} i-s ̌ u m$

Šumanum,

Servant of Išum

Comment: Though little attested during the Kassite period, the name Šumanum does appear in earlier economic records, dating to the reign of Ur III ruler Amar-Sîn, in texts from the administrative center of Puzrish-Dagan. In these texts, Šumanum is referred to as one of a number of Amorite individuals (identified by the formula of personal name [PN] $m a r-t u$ ) who appear in the texts. Though entirely distinct from the Kassites, the Amorites were similarly foreign to Mesopotamia. ${ }^{44}$

Publication: Metropolitan Museum 1999

MMA 1999.325.61 (fig. 4)

A male royal or divine figure wearing a short kilt and a headdress stands holding a mace and with a line drawn beneath him. Facing him, and away from the four-line inscription, is a supplicant figure wearing a fringed robe.

Agate, H. $7 / 8$ in. $(2.3 \mathrm{~cm})$

Gift of Nanette B. Kelekian, in memory of Charles Dikran and

Beatrice Kelekian, 1999

Inscription:

ma-an- ${ }^{\top} b a^{\top}-s_{i}$

DUMU.MUNUS ${ }^{d} U T U-b i^{?}-r a^{?}-q u ̀-u r$

GEME$_{2}{ }^{\mathrm{d}}$ AMAR.UTU

$\mathrm{U}_{3}{ }^{\mathrm{d}}$ Șar'-pa-ni-tum

Manbaši,

Daughter of Šamaš-..

Female servant of [the god] Marduk

And [the goddess] Șarpanitum

Comment: Little can be said with certainty about the name Manbaši. It is most likely a Kassite name rather than an Akkadian one since it more closely matches the general format of Kassite names. ${ }^{45}$ The name of Manbaši's father, on the other hand, conforms more properly to Akkadian standards, and it begins with the name of the god Šamaš, though the latter half of the name is not clear. Manbaši states that she is the servant of the god Marduk and his consort Sarpanitum, who appears on her own in the inscription on MMA 47.115.3 (fig. 1). ${ }^{46}$ Publication: Metropolitan Museum 1999
1 On the Kassites and their rule in Babylonia, see Brinkman 1976, which remains a major compilation of the published cuneiform texts relating to the Kassite period. On the ruling monarchy, particularly its foreign nature, see Brinkman 1974 and Malko 2014

2 The single example that is not stone is MMA 56.81.24 (fig. 9), which was carved in faience. For a discussion of that material, see Riccardelli 2017.

3 Serdar Yalçın (2016, p. 130) reports that within the Kassiteperiod corpus just fourteen seals can be "securely attributed" to women. Of the seals belonging to the Metropolitan Museum, he cites only MMA 1985.357.44 (fig. 3), omitting the other three. In the case of MMA 47.115 .3 (fig. 1), this exclusion is based on the difficulty in identifying the seal definitively as late Old Babylonian or early Kassite.

4 On the Kassite language, see Ancillotti 1981.

5 Here the term "servant" is primarily metaphorical, indicating a connection and devotion to a particular deity rather than a particular religious or social position. For information on transliteration conventions and determinatives in Sumerian and Akkadian, see "A Note on the Transliteration of Inscriptions" in the Appendix of this article.

6 Styles of Kassite glyptic art were laid out first, with just two styles, in Van Buren 1954; then expanded in Beran 1957-58; and presented most recently in Collon 2007. They are described in depth in Matthews 1990, p. 55. Donald Matthews also identifies a fourth, pseudo-Kassite, style derived from First Kassite style.

7 Carnelian cylinder seals from other periods are present in the Museum's collection; see, for example, MMA 41.160.317 and MMA 1999.325.71, both from the first millennium B.C. On the grave goods at Ur, see Reade 2001, pp. 23-26.

8 A general overview of Nergal may be found in Wiggermann 1998-2001.

9 Șarpanitum's shrine and her association with a processional way are both later attestations, but they may point to her developing significance as a deity independent of her spouse Marduk. See George 1992, pp. 414-15.

10 For an overview of Gula, see Böck 2014, pp. 7-44.

11 On Gula and her connection to dogs, see Ornan 2004.

12 Römer 1969; note that this text refers to Gula by the Sumerian name Ninisina.

13 For earlier cylinder seals with representations of Šamaš and Aya, see MMA 41.160.329 and MMA 1999.325.13.

14 For example, in the Akkadian Epic of Gilgamesh, Ninsun, the mother of the text's titular hero, appeals directly to Aya to protect her son on his adventures, asking her to ensure that her husband Šamaš will protect him.

15 For an overall comprehensive look at Amurru, see Kupper 1961 and Beaulieu 2005.

16 Regarding the curved staff associated with a number of deities, including Amurru, see Ambos and Krauskopf 2010

17 As seen in the incantation series Maqlû Tablet VI:4, in which a number of deities are invoked in reference to the protection of specific body parts: "My arms are the crook ( $\mathrm{gam} / \mathrm{u}$ ) of Sîn and Amurru!" See Abusch 2016, p. 339.

18 On this stele and its inscription, see Becker 1993, p. 59, no. 791.

19 Perhaps the best example of a more lifelike image of a fly on a cylinder seal is found at the British Museum, BM 128843, an early third millennium B.C. cylinder seal that is uninscribed but is carved with images of two ibex and a recumbent gazelle, with a precisely detailed fly above it. 
20 See George 2003, vol. 1, pp. 712-15. This passage appears on Tablet XI, lines 161-71.

21 See, for example, Pittman 1998.

22 See a listing of such seals in Tanret 2010, p. 220

23 Although we see that this is true for most periods in Mesopotamian history, there are several periods during which we see women participate in economic activity, such as the long-distance trading networks between Mesopotamia and Anatolia of the early second millennium B.C.

24 See Hurowitz 2010, p. 91. The use of ${ }^{\mathrm{d}} \mathrm{š}_{3} . z u$ for Marduk also appears on a seal inscription found in Megiddo: ${ }^{\circ} \mathrm{S}_{3}-\mathrm{ZU} /[b] e ́-l i-i$ / ARHUŠ TUKU.HA; Šazu (=Marduk), my lord, have mercy (on me); see Oshima 2014, pp. 40-41. This inscription is repeated on an early Kassite seal in the Morgan Library and Museum; see Porada and Buchanan 1948, no. 576.

25 Huehnergard 1999, p. 375.

26 In particular, we see a listing for four attestations of Ageya (read as a-gi-ia/a-qi-ia) even within Albert T. Clay's collection of Kassite-period personal names: a ruler; the father of one Enmaštu-nâdin-šum; the father of one Mindi-iballut; and appearing once in texts from Amarna. See Clay 1912, p. 50, and Hölscher 1996, p. 22.

27 The reading is suggested in Lilyquist 1994, p. 36.

28 The First Kassite Style is defined in Van Buren 1954, p. 4.

29 On the Sippar cloister, or Gagûm, and the women who lived there, see Richardson 2010, p. 340.

30 Lilyquist 1994, p. 36. We see attestations of a female name, Lammassūtu, in Kassite personal names from Nippur; see Hölscher 1996, p. 130.

31 Gentili 1996, pp. 100-103.

32 Clay 1912, p. 120

33 In particular, J. A. Brinkman presents the use of Emesal on one of a group of seals found at Thebes, with the use of umun = en and $\mathrm{i}-\mathrm{bi}_{2}$ as the Emesal for igi and e-re as Emesal for arad. See Brinkman 1981-82, p. 76, no. 34. The use of umun-gal is attested several times on Kassite cylinder seal inscriptions; see the Kassite seal inscription beginning ${ }^{d}$ EN.ZU UMUN.GAL (Porada and Buchanan 1948, no. 579, and ibid., nos. 584, 585, which also begin dUTU UMUN-GAL).

34 See Bahrani 2006, p. 54

35 Delaporte 1920, no. 22. See also Morgan Library and Museum seal no. 121, http://corsair.themorgan.org/cgi-bin/Pwebrecon .cgi?BBID $=83743$.

36 Wiggermann 1985-86, pp. 3-7, 14.

37 Wall-Romana 1990.

38 This name is more frequently written $\mathrm{zalag}_{2}{ }^{-\mathrm{d} u t u}$ in Sumerian, rather than ud-dutu, as seen here; Hölscher 1996, p. 162.

39 Regarding this seal of Ahuni as the cupbearer of Šu-Sîn, see Fischer 2008, pp. 72-73.

40 We see, for example, "Ahuni, son of Šamaš-rabi, servant of Šamaš" (a-hu-ni / DUMU dUTU-ra-bi / ARAD dUTU) on an Old Babylonian seal in the Morgan Library and Museum (Porada and Buchanan 1948, no. 315), and other attestations in Hölscher 1996, p. 25

41 There is little information specifically about Mamitum, who decided the fates of those entering the netherworld. See Lambert 1973.

42 Porada and Buchanan 1948, no. 429.

43 lbid., no. 527.

44 Liu 2015, pp. 94-97. Concerning this and other Amorite personal names during this period, see Buccellati 1966, p. 182, and Owen
1995. Šumanum in particular was awarded three sheep, and was thus integrated into Ur III bureaucracy despite his foreign origin.

45 Among the Kassite names found inscribed on objects in the collection of the Museum, we see most prominently the king Nazi-Maruttaš on an inscribed stele of a protective Lama goddess (fig. 15).

46 The pairing of Marduk and Sarpanitum is far more common in cylinder seal inscriptions than Sarpanitum's appearing alone as she does in figure 1. I am grateful to Piotr Michalowski for his help with this seal's inscription.

\section{REFERENCES}

Abusch, I. Tzvi

2016 The Magical Ceremony Maqû: A Critical Edition. Ancient Magic and Divination 10. Leiden: Brill.

Ambos, Claus, and Ingrid Krauskopf

2010 "The Curved Staff in the Ancient Near East as a Predecessor of the Etruscan lituus." In Material Aspects of Etruscan Religion: Proceedings of the International Colloquium Leiden, May 29 and 30, 2008, edited by L. Boulke van der Meer, pp. 127-53. Leuven and Walpole, Mass.: Peeters.

Ancillotti, Augusto

1981 La lingua dei Cassiti. Milan: Unicopli.

Bahrani, Zainab

2006 "Race and Ethnicity in Mesopotamian Antiquity." World Archaeology 38, no. 1, Race, Racism and Archaeology (March), pp. 48-59.

Beaulieu, Paul-Alain

2005 "The God Amurru as Emblem of Ethnic and Cultural Identity?" In Ethnicity in Ancient Mesopotamia: Papers Read at the 48th Rencontre Assyriologique Internationale Leiden, 1-4 July 2002, edited by W. H. van Soldt in cooperation with R. Kalvelagen and D. Katz, pp. 31-46. Leiden: Nederlands Instituut voor het Nabije Oosten.

Becker, Andrea

1993 Uruk: Kleinfunde. Vol. 1, Stein. Ausgrabungen in UrukWarka, Endberichte 6. Mainz am Rhein: Philipp von Zabern.

Beran, Thomas

1957-58 "Die babylonische Glyptik der Kassitenzeit." Archiv für Orientforschung 18, pp. 255-78.

Böck, Barbara

2014 The Healing Goddess Gula: Towards an Understanding of Ancient Babylonian Medicine. Culture and History of the Ancient Near East 67. Leiden: Brill.

Brinkman, J. A.

1974 "The Monarchy in the Time of the Kassite Dynasty." In Le palais et la royauté: Archéologie et civilisation; XIXe Rencontre Assyriologique Internationale, Paris, 29 juin-2 juillet 1971, edited by Paul Garelli, pp. 395-408. Paris: Librairie Orientaliste P. Geuthner.

1976 Materials and Studies for Kassite History. Vol. 1, A Catalogue of Cuneiform Sources Pertaining to Specific Monarchs of the Kassite Dynasty. Chicago: Oriental Institute of the University of Chicago.

1981-82 "The Western Asiatic Seals Found at Thebes in Greece: A Preliminary Edition of the Inscriptions." Archiv für Orientforschung 28, pp. 73-78. 
Buccellati, Giorgio

1966 The Amorites of the Ur III Period. Naples: Istituto Orientale di Napoli.

Clay, Albert T.

1912 Personal Names from Cuneiform Inscriptions of the Cassite Period. Yale Oriental Series 1. New Haven: Yale University Press; London: Henry Frowde Oxford University Press.

Collon, Dominique

2007 "Material Culture: Babylonian Seals." In The Babylonian World, edited by Gwendolyn Leick, pp. 95-123. New York and London: Routledge.

Delaporte, Louis

1920 Catalogue des cylindres, cachets et pierres gravées de style orientale, Musée du Louvre. Paris: Hachette.

Eisen, Gustavus A.

1940 Ancient Oriental Cylinder and Other Seals with a Description of the Collection of Mrs. William H. Moore. Oriental Institute Publications 47. Chicago: University of Chicago Press.

Fischer, Claudia

2008 "Of Kings and Cups." In The Growth of an Early State in Mesopotamia: Studies in Ur III Administration; Proceedings of the First and Second Ur III Workshops at the 49th and 51st Rencontre Assyriologique Internationale, London, July 10, 2003 and Chicago, July 19, 2005, edited by Justin Cale Johnson and Steven J. Garfinkle, pp. 63-78. Madrid: Consejo Superior de Investigaciones Científicas.

Gentili, Paolo

1996 "Tabelle Razionarie da Mari." Egitto e Vicino Oriente 19 pp. 89-120.

George, A. R.

1992 Babylonian Topographical Texts. Orientalia Lovaniensia Analecta 40. Leuven: Uitgeverij Peeters en Departement Oriëntalistiek.

2003 The Babylonian Gilgamesh Epic: Introduction, Critical Edition, and Cuneiform Texts. 2 vols. Oxford and New York: Oxford University Press.

Herzfeld, Ernst

1923-46 "Inventory of Objects in Herzfeld Collection (N-90)." The Ernst Herzfeld Papers, Series 3: Notebooks. Freer Gallery of Art and Arthur M. Sackler Gallery Archives, Smithsonian Institution, Washington, D.C.

Hölscher, Monika

1996 Die Personennamen der kassitenzeitlichen Texte aus Nippur. IMGULA 1. Münster: Rhema.

Huehnergard, John

1999 "The Akkadian Letters." In Handbook of Ugaritic Studies, edited by W. G. E. Watson and N. Wyatt, pp. 375-89. Leiden and Boston: Brill.

Hurowitz, Victor Avigdor

2010 "Name Midrashim and Word Plays on Names in Akkadian Historical Writings." In A Woman of Valor: Jerusalem Ancient Near Eastern Studies in Honor of Joan Goodnick Westenholz, edited by Wayne Horowitz, Uri Gabbay, and Filip Vukosavović, pp. 87-104. Biblioteca del Próximo Oriente Antigua 8. Madrid: Consejo Superior de Investigaciones Científicas.

Imai, Ayako

1983 "Seals (Nos. 110-153)." In The Metropolitan Museum of Art: Selections from the Collection of the Ancient Near East Department. Exh. cat., Seibu Museum of Art. Tokyo: Chunich Shimbum.
Kupper, Jean Robert

1961 L'iconographie du dieu Amurru dans la glyptique de la Ire dynastie babylonienne. Brussels: Palais des Académies.

Lambert, W. G.

1973 "Studies in Nergal." Bibliotheca Orientalis 30, pp. 355-63.

Lilyquist, Christine

1994 “The Dilbat Hoard." MMJ 29, pp. 5-36.

Limet, Henri

1971 Les légendes des sceaux cassites. Brussels: Palais des Académies.

Liu, Changyu

2015 "Organization, Administrative Practices, and Written Documentation at Puzriš-Dagan during the Reign of Amar-Suen." PhD diss., Universität Heidelberg.

Malko, Helen 0 .

2014 "Investigation into the Impacts of Foreign Ruling Elites in Traditional State Societies: The Case of the Kassite State in Babylonia (Iraq)." PhD diss., Stony Brook University.

Matthews, Donald M.

1990 Principles of Composition in Near Eastern Glyptic of the Later Second Millennium B.C. Orbis Biblicus et Orientalis, Series Archaeologica, 8. Freiburg: Universitätsverlag; Göttingen: Vandenhoeck und Ruprecht.

Metropolitan Museum

1985 "Curatorial Reports and Departmental Accessions: Ancient Near Eastern Art." In The Metropolitan Museum of Art: Annual Report for the Year 1985-1986, pp. 15-16. New York: MMA. 1999 "Departmental Accessions: Ancient Near East." In The Metropolitan Museum of Art: Annual Report for the Year 19992000, p. 9. New York: MMA.

Ornan, Tallay

2004 "The Goddess Gula and Her Dog." Israel Museum Studies in Archaeology 3, pp. 13-30.

Oshima, Takayoshi

2014 Babylonian Poems of Pious Sufferers: Ludlul Bel Nemeq and the Babylonian Theodicy. Orientalische Religionen in der Antike 14. Tübingen: Mohr Siebeck.

Owen, David I.

1995 "Amorites and the Location of BÀD $\{\mathrm{ki}\} . "$ In Immigration and Emigration within the Ancient Near East: Festschrift E. Lipiński, edited by K. Van Lerberghe and A. Schoors, pp. 21319. Orientalia Lovaniensia Analecta 65. Leuven: Uitgeverij Peeters en Departement Oriëntalistiek.

Paulus, Susanne

2014 Die babylonischen Kudurru-Inschriften von der kassitischen bis zur frühbabylonischen Zeit: Untersucht unter besonderer Berücksichtigung gesellschafts- und rechthistorischer Fragestellungen. Alter Orient und Altes Testament 51. Münster: Ugarit-Verlag.

Pittman, Holly

1998 "Jewelry: Strings of Beads" and no. 69. In Treasures from the Royal Tombs of Ur, edited by Richard L. Zettler and Lee Horne, pp. 110-12. Exh. cat. Philadelphia: University of Pennsylvania, Museum of Archaeology and Anthropology.

Pittman, Holly, in collaboration with Joan Aruz

1987 Ancient Art in Miniature: Near Eastern Seals from the Collection of Martin and Sarah Cherkasky. New York: MMA.

Porada, Edith, in collaboration with Briggs Buchanan 1948 Corpus of Ancient Near Eastern Seals in North American Collections. Vol. 1, The Collection of The Pierpont Morgan Library. Bollingen Series 14. New York: Pantheon Books. 
Price, Ira Maurice

1908 "Some Cassite and Other Cylinder Seals." In Old

Testament and Semitic Studies in Memory of William Rainey

Harper, edited by Robert Francis Harper, Francis Brown, and

George Foot Moore, vol. 1, pp. 383-400. Chicago: University of Chicago Press.

Reade, Julian

2001 "Assyrian King-Lists, the Royal Tombs of Ur, and Indus Origins." Journal of Near Eastern Studies 60, no. 1 (January), pp. 1-29.

Riccardelli, Carolyn

2017 "Egyptian Faience: Technology and Production." In Heilbrunn Timeline of Art History. New York: MMA, 2000http://www.metmuseum.org/toah/hd/egfc/hd_egfc.htm (December).

Richardson, Seth

2010 "A Light in the Gagûm Window: The Sippar Cloister in the Late Old Babylonian Period." In Opening the Tablet Box: Near Eastern Studies in Honor of Benjamin R. Foster, edited by Sarah C. Melville and Alice L. Slotsky, pp. 329-46. Culture and History of the Ancient Near East 42. Leiden: Brill.

Römer, Willem H. Ph.

1969 "Einige Beobachtungen zur Göttin Nini(n)sina auf Grund von Quellen der Ur III-Zeit und der altbabylonischen Periode." In lišān mit[h]urti: Festschrift Wolfram Freiherr von Soden zum 19. VI. 1968 gewidmet von Schülern und Mitarbeitern, edited by Wolfgang Röllig and Manfried Dietrich, pp. 279-305. Alter Orient und Altes Testament 1. Kevelaer, Germany: Butzon \& Bercker; Neukirchen-Vluyn, Germany: Neukirchener Verlag des Erziehungsvereins.
Sayce, A. H.

1877 "The Babylonian Cylinders Found by General di Cesnola in the Treasury of the Temple at Kurium." Transactions of the Society of Biblical Archaeology 5, part 1 (June), pp. 441-44. Tanret, Michel

2010 The Seal of the Sanga: On the Old Babylonian Sangas of Šamaš of Sippar-Jahrūrum and Sippar-Amnānum. Cuneiform Monographs 40. Leiden and Boston: Brill.

Van Buren, E. Douglas

1954 "The Esoteric Significance of Kassite Glyptic Art." Orientalia, n.s., 23, no. 1, pp. 1-39.

Wall-Romana, Christophe 1990 "An Areal Location of Agade." Journal of Near Eastern Studies 49, no. 3 (July), pp. 205-45.

Ward, William Hayes

1895 Seal Cylinders and Other Oriental Seals. MMA Hand-Book No. 12. New York: MMA.

1910 The Seal Cylinders of Western Asia. Washington, D.C.: Carnegie Institute of Washington.

Wiggermann, F. A. M.

1985-86 "The Staff of Ninšubura: Studies in Babylonian Demonology, II." Jaarbericht van het Vooraziatsch-Egyptisch Genootschap Ex Oriente Lux 29, pp. 3-34

1998-2001 "Nergal." In Reallexikon der Assyriologie und Vorderasiatischen Archäologie, vol. 9, pp. 215-26. Berlin: Walter de Gruyter.

Yalçın, Serdar

2016 "Men, Women, Eunuchs, Etc.: Visualities of Gendered Identities in Kassite Babylonian Seals (ca. 1470-1155 B.C.)." Bulletin of the American Schools of Oriental Research, no. 376 (November), pp. 121-50. 